\title{
Baia Mare Geological and Mining Park - a potential new Geopark in the northwestern part of Romania
}

\author{
Marinel KOVACS* \& Alexandrina FÜLÖP
}

North University Baia Mare, 430083 Baia Mare, Romania

Received March 2009; accepted May 2009

Available online June 2009

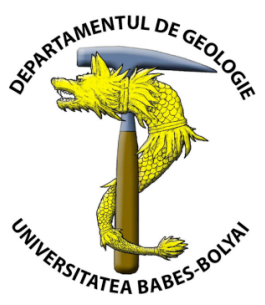

\begin{abstract}
The Baia Mare region is a very well known mining area, with an excellently studied regional geology in Romania. The geological heritage has been strongly incorporated in the economic and social development of the region which is now subject to the cease of the mining-based activities. The natural heritage, as well as the historical and cultural values of the region, will contribute substantially to the future development. The region of Baia Mare has a high potential for founding a new Geopark in the Gutâi Mts. volcanic area. The main geological, mining/archaeological/historical, ecological and cultural issues of the Baia Mare region offer opportunities for protection and conservation, education and sustainable development, in accordance with the UNESCO guidelines and criteria for establishing a Geopark in a new region. These issues are based on the scientific value, esthetics and a specific geology and mining. This indicates that the impressive natural heritage, as well as the hundreds of years of mining in Baia Mare region, opens a good opportunity to call for a new "Geological and Mining Park" in Romania as a real social and economic alternative for the development of the local communities.
\end{abstract}

Key words: geology, mining, natural heritage, geopark, Baia Mare, conservation, sustainable development.

\section{INTRODUCTION}

The Baia Mare region is a well known mining area, with a well studied regional geology. The geological and mining heritage opens a huge potential for the region, including a possibility for education on undergraduate and post-graduate levels in geology and environmental protection and for sustainable development of the local communities.

The economic and social development in the region is strongly related to the geological heritage. The mining of gold-silver, lead-zinc and copper ore deposits had been the main economic activity for many centuries, but its decline after 1990 created a serious economic and social problem. A sustainable development of Baia Mare region can be achieved, in part, based on the potential of the geological heritage transforming the area into a Geopark.

The proposal of a Geopark in Baia Mare region is in accordance with the enhancing development of the new concept promoted by the international organizations such as UNESCO. The UNESCO Global Geoparks and European Geoparks Networks are involved in the protection and conservation of the geological heritage and, in this respect, in the protection of the territories hosting it. UNESCO defines a Geopark or a geological park as "a territory encompassing one or more sites of scientific importance, not only for geological reasons, but also by virtue of its archaeological, ecological and cultural value" (www.unesco.org/science/earth/doc/geopark/2008guidelines).

The paper aims to outline the importance of the geodiversity and mining, as well as the historical and cultural values of Baia Mare region, with respect to sustain *Correspondence: M. Kovacs (marinelkovacs@yahoo.com) and support the idea of a new Geopark in Romania. Following the UNESCO guidelines and criteria to establish a Geopark in a new region, we attempt to summarize the main issues of Baia Mare region, in terms of geological, mining/archaeological/historical, ecological and cultural aspects, aiming towards protection and conservation, education and sustainable development.

\section{GEOLOGICAL HERITAGE}

The area of the potential Geopark covers the Gutâi Mts., one of the most complex volcanic areas from the Neogene Inner Carpathians volcanic arc. The volcanism building up the Gutâi Mts. developed between 15.4-7.0 Ma, consisting of two different types: a felsic, extensional-type and an intermediate, arc-type respectively, responsible for various structures, products and rock types (Kovacs and Fülöp, 2003). The felsic volcanism is represented by rhyolitic rocks and the intermediate volcanism consists of a calc-alkaline series, ranging from basalts to rhyolites. The metallogenic activity developed in connection with the intermediate, arctype volcanism, in the southern part of the mountains, whereby a number of gold-silver and lead-zinc ore deposits (subordinately with copper and gold) are aligned from the west to the east.

The Baia Mare region shows many geological sites of scientific interest, some of them already established as protected areas, in accordance with the International Union for Conservation of Nature and Natural Resources (IUCN) classification (natural monuments or scientific reserves, I to 
IV categories). Most of these geosites are very well documented by some Ph.D. theses or scientific papers and books. We outline some of the most representative geological sites (Fig. 1):

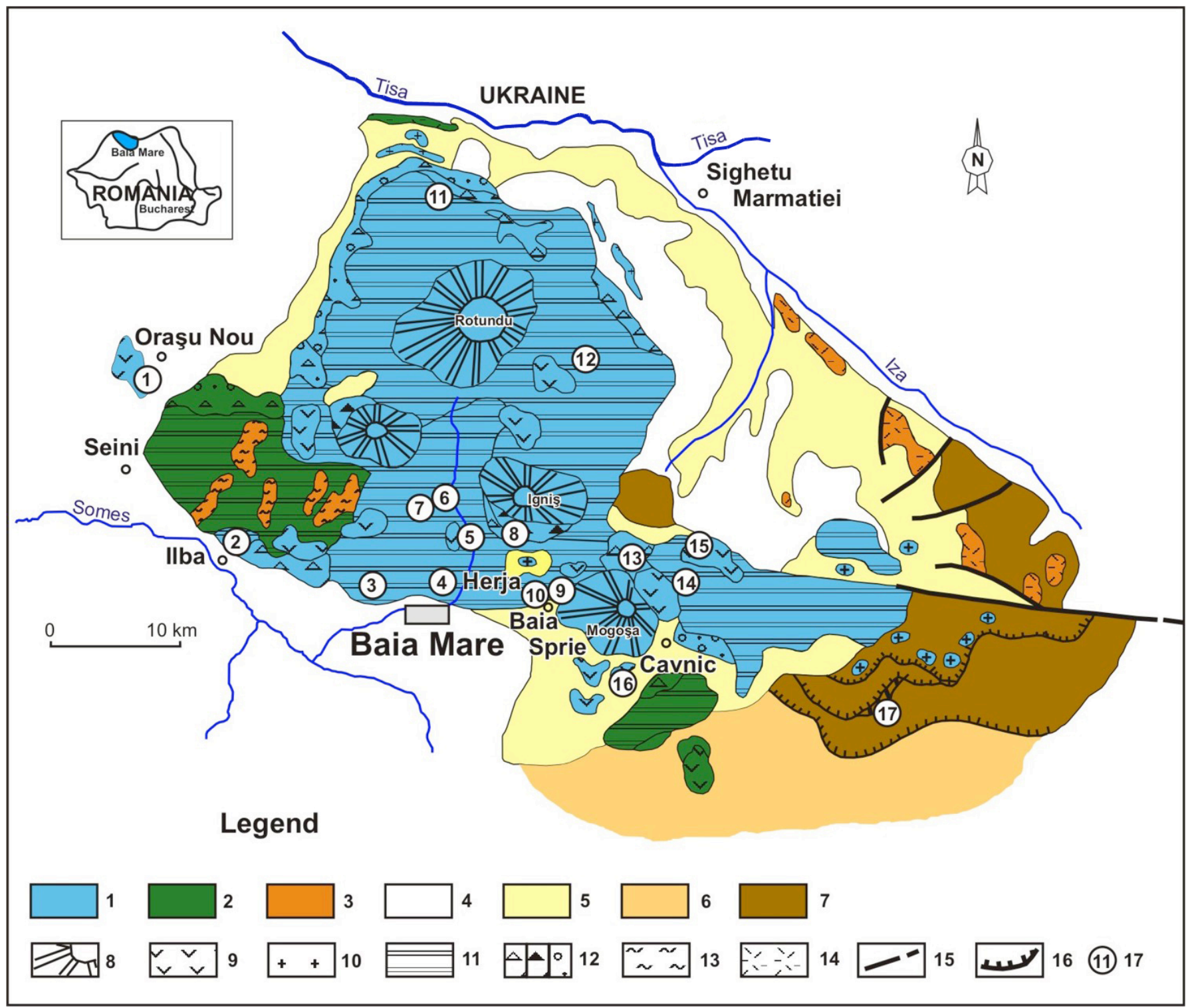

Fig. 1. Geological/volcanological map of the Baia Mare region/Gutai Mts. (after Kovacs et al., 2006) with location of some representative geosites. Legend: 1. Pannonian volcanics; 2. Sarmatian volcanics; 3. Badenian volcanics; 4. Quaternary; 5. Neogene sedimentary deposits; 6. Oligocene-Miocene sedimentary deposits; 7. Paleogene sedimentary deposits; 8. Effusive cones; 9. Extrusive domes; 10. Intrusions; 11. Volcano-tectonic depression effusive filling; 12. Pyroclastic and epiclastic deposits; 13. Ignimbrites and associated volcaniclastics; 14. Primary and reworked tuffs; 15. Faults; 16. Overthrusts; 17. Geosites: 1, Orasu Nou rhyolitic perlites; 2, Ilba andesitic Rosette Stone; 3, Hydrothermal adularia-quartz alterations in the Toncii valley (Sasar ore deposit); 4, Dealul Crucii mine (Middle Age adits); 5, Limpedea pillars, Ferneziu; 6, Paleogene flysch as tectonic window; Firiza Lake; 7, Welded ignimbrites

on the Romana valley, Firiza; 8, Chiuzbaia fossiliferous scientific reserve; 9, Mine Hill, Baia Sprie; 10, Blue Lake; 11, Piatra

Sapintei Peak; 12, Tatarului Quays; 13, Laleaua Alba quarry; 14, Suior mine; open pit; 15, Rooster's Ridge/Creasta Cocosului; 16, Piatra Rosie Hill, Surdesti; 17, Poiana Botizei Pienniny Klippen Belt.

a. Well-defined volcanic structures and various rock types: the Rotundu crater and the Igniş and Mogoşa andesitic effusive cones (Fig. 1); some extrusive domes should be also nominated e.g. the Oraşu Nou rhyolitic dome (no. 1 in Fig. 1), the Dănesti-Piatra Roşie interconnected domes complex (no. 16 in Fig. 1), the Pleşca Mare andesiticdacitic composed dome and the Gutin andesitic cumulodome (no. 15 in Fig. 1).

b. Petrographical, structural and textural features: the Coroana de Aur (Nistru) rhyolitic welded ignimbrites and the Romană valley (Firiza, no. 7 in Fig. 1) welded ignimbrites with gas escape structures (Fülöp, 2003); the Piatra Roşie Hill (Surdesti, no. 16 in Fig. 1) hyaloclastites and reworked volcaniclastics (Fig. 3), the Gutin winding Studia UBB, Geologia, 2009, 54 (1), 27 - 32 road and the Pintea Viteazu cave submarine rootless explosive volcaniclastics; the vertical columnar jointings such as those from Ferneziu (Limpedea pillars, no. 5 in Fig. 1) and the radial columnar jointings such as those from the Ilba Rosette Stone (no. 2 in Fig. 1 and Fig. 2), both of them established as natural monuments included into the III category of IUCN classification; the vacuoles and bedding in the Oraşu Nou rhyolitic dome with perlites unique in Romania, the Laleaua Albă quartz andesites and dacites with gabbroic cognate xenoliths (no. 13 in Fig. 1) and many others with outstanding features shown up in well exposed outcrops or quarries.

c. Interesting tectonic elements and features. The tectonic windows exposing the buried Paleogene basement (e.g. 
accessible outcrops near the Firiza Lake, no. 6 in Fig. 1 and Ulmoasa - Băița), constraints for the main transcrustal Cârlibaba-Carei fault, the prolongation of the Mid Hungarian Line according to Csontos and Nagymarosy (1998) - highly significant for the Cenozoic geotectonic evolution of the Carpatho-Pannonian Region, the occurrences of the Pieninny Klippen Belt (Jurassic-Cretaceous) in the Poiana Botizei area, and the overthrust units of the Trancarpathians flysch from the Băiuț-Poiana Botizei area, document the main Carpathian orogenic phases.

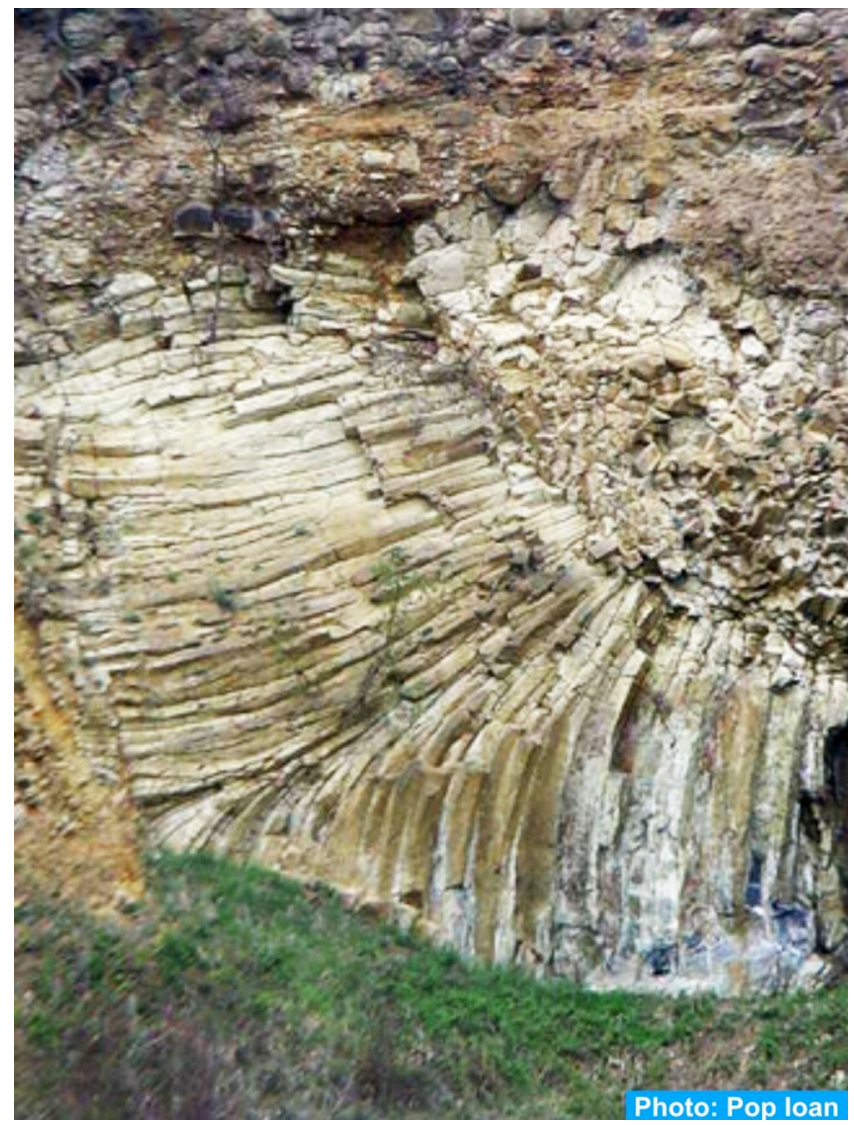

Fig. 2. The Ilba andesitic Rosette Stone (natural monument, IIIrd IUCN).

d. Sedimentary deposits. Besides the above-mentioned Paleogene flysch-type sedimentary deposits, some geosites consist of Badenian sedimentary deposits with interbedded volcaniclastics (e.g. Limpedea valley - Băița), Sarmatian and Pannonian, often fossiliferous deposits with thin layers of reworked volcaniclastics (e.g. Satul valley - Racşa, Săsar and Cavnic valleys).

e. Hydrothermal mineralisations/ore deposits. The Baia Mare region is famous in Europe for the mined gold-silver and base metal ore deposits which are very well documented as typical low sulphidation, predominant vein-type mineralisations (Kovacs, 2001). Hundreds of veins (e.g. the Main Vein in the Baia Sprie mine; with its $8 \mathrm{~km}$, is the longest ore vein in Europe) had been mined in more than 20 mines during the last 25 years, until 2007. Two of the ore deposits, Cavnic and Baia Sprie, were classified as "world class deposits" and some of them were described as "typical type" in the scientific literature (e.g the "intrusion-related carbonate base-metal gold" Cavnic ore deposit and the “quartz gold-silver" Săsar ore deposit).

Besides the recently closed mines which can be developed in the near future as mining museums, some open pits and outcrops already form geosites related to the ore deposits: the Mine Hill - open pit of the Baia Sprie mine (no. 9 in Fig. 1), the Suior quarry (no. 14 in Fig. 1) - the upper part of the closed open pit of the Şuior mine, the Mare valley - Nistru ore deposit, the Cavnic and Şuior valleys in the upper part of the Cavnic ore deposit, etc. Some of the geosites are related to typical hydrothermal alterations such as adularia-quartz/sericite type (e.g., the Mine Hill Baia Sprie, the Toncii valley, no. 3 in Fig. 1 and the Poprad Hill Săsar ore deposit).

f. Minerals and fossils. Mineral and fossil occurrences of international interest form significant geosites in Baia Mare region. The Baia Sprie, Săsar, Cavnic and Herja mines are type localities for a series of minerals such as: andorite, szmikite, felsöbányaite, semseyite, fizelyite, fülöppite, klebersbergite, parajamesonite, and host of esthetic and rare mineral samples known as "mine flowers", exposed in the Mineralogy Museum of Baia Mare city and in other important museums from Budapest, Vienna, Prague, Berlin, Bucharest, etc. The impressive collection of the Mineralogy Museum, consisting of more than 17000 outstanding mineral samples, represents a testimony for the exceptional mineralogical value of Baia Mare region. The Chiuzbaia fossiliferous scientific reserve (I IUCN category; no. 8 in Fig. 1) consisting of one of the most representative Neogene flora from Europe, with new species first time classified hereby, represents one of the most important geosites in Baia Mare region. It is located close to the Baia Mare city, in the vicinity of the Igniş volcano. Other Paleogene and Neogene deposits with fossil flora and fauna occur in the surrounding area.

g. Landforms/landscape sites. Many impressive landscapes in the region are related to the geomorphological features of the volcanic structures, statutory- or non statutoryprotected areas: e.g. the Rooster's Ridge (Creasta Cocoşului; no. 15 in Fig. 1), III IUCN category natural monument in the Gutâi Massif (north of Cavnic), the Tătarului Gorges (III IUCN category natural monument, no. 12 in Fig. 1) in the northern slope of the Gutâi Mts., the Piatra Săpânței (no. 11 in Fig. 1), a big scar at the boundary of the volcanic zone and the Maramureş Basin in the northern part of the Gutâi Mts, the Mogoşa Peak from the Mogoşa volcano, the Piatra Roşie Hill near Şurdeşti village, etc.

h. Ecological sites. Most of these sites are related to geological formations and established as natural monuments and reserves (III - IV IUCN categories) due to the scientific importance of the consisting biodiversity. Some of them occur in the northern slope of the the Gutâi Mts - the Poiana Brazilor and Vlăşinescu marshes, the Iezerul Mare Peatery and the Dumitru's Pond. The Creasta Cocoşului (III IUCN category), the Morăreni Lake (IV IUCN category) and the Black Pond Peatery (III IUCN category) are among the most interesting sites located in the eastern part of the volcanic zone. An amazing ecological site in the region, the Blue Lake (near the Baia Sprie town, no. 10 in Fig. 1) is a mining-derived statutory - protected (III IUCN category) area, unique in Romania due to its aquatic habitat.

i. Mining/archaeological sites. Mining has been important in the region for centuries. The Baia Mare city has been known from the XIVth century (Rivulus Dominarum), as well as the Baia Sprie town (Mons Medius), developed around the mining activity, as certified by official documents. During the XIV- XVIIth centuries, numerous mines were working around Baia Mare, Baia Sprie and Cavnic. New mines have been open in Baiut, Ilba, and Studia UBB, Geologia, 2009, 54 (1), 27 - 32 
Nistru during the XVIII and XIXth centuries. The mining was active until 2007, many of the mines being now in conservation.

All around the mining zones there are many interesting sites, related both to the very old mines (Middle Age) and to the more recent ones. It is worth to mention some of the most significant sites: the "Smoke gallery" from the Dealul Crucii mine (near Baia Mare; no. 4 in Fig. 1) as testimony of the „fire exploitation" in the Middle Age (Istvan and Minghiras, 2004), the Lobkovitz (Heilige Kreuz - Dealul Crucii), Borcut (Baia Sprie mine) and Reiner (first named Odon - Cavnic mine) adits, built up in the XVII - XVIII ${ }^{\text {th }}$ centuries, the Francisc shaft building (Baia Sprie mine), built up between 1831-1835 (Bud et al., 2006). Some other representative historical sites related to the mining activity should be mentioned as well, some old buildings or ruins such as the administrative buildings or miners residences from the Baia Sprie and Cavnic towns from the XVIIIth and XIXth centuries or the cyanide refinery from the Cavnic mine, among the first refineries in the world (Bud et al., 2006). Many artifacts and old mining tools can be seen in the Mining Museum which is a section of the History and Archaeology Museum of the Maramures County, in Baia Mare city.

j. International and national geological interest of the region. The Baia Mare region is one of the best studied areas in Europe. It has been an important geological research area for more than 300 years. Hundreds of Romanian and foreign geologists and geoscientists studied the geology of the region and, with this respect, important papers have been published on topics including the mineralogy, petrology, volcanology, metallogeny, tectonics and paleontology of Baia Mare region. The Baia Mare region still represents a challenge for the geological research, although thousands of geological reports, studies and papers have been achieved during the last 50 years. Some important geological international conferences and projects that took place in the last years in Baia Mare region testify for the international scientific interest on the area.

\section{OPPORTUNITIES AND COMMITMENTS REGARDING THE POTENTIAL BAIA MARE GEOPARK}

The geological, mining/archaeological/historical, ecological and cultural (many UNESCO/ World Heritage Patrimony sites) values of the Baia Mare region have a huge potential and, in accordance, represent a strong argument for the foundation of a Geopark in the area. Many opportunities are developing in the region in this respect, but some commitments need to be made, following the UNESCO guidelines and criteria for establishing a new Geopark in a region. The main issues are focused on the protection and conservation, education and sustainable development involving regional and local authorities, academic institutions and non-governmental organizations.

\section{Protection and conservation}

The UNESCO guidelines and criteria for National Geoparks emphasize that "a Geopark is not a specifically new category of protected area" and that „, the responsible Geopark authority ensures the protection of the geological heritage of the Geopark in accordance with local traditions Studia UBB, Geologia, 2009, 54 (1), 27 - 32 and legislative obligations" (www.unesco.org/science /earth/doc/geopark/2008guidelines). The significant geological features worth to be protected according to the UNESCO guidelines are representative rocks, mineral resources, minerals, fossils, landforms and landscapes. We suggest such representative geological features, involving protection for future conservation in Baia Mare region:

a. Representative rocks: the Jurassic-Cretaceous limestones in the Poiana Botizei Pienniny klippen Belt (no. 17 in Fig. 1), the Oraşu Nou rhyolitic perlites (no. 1 in Fig. 1), the Romană valley-Firiza welded ignimbrites with gas escapes structures (no. 7 in Fig. 1), the Laleaua Albă quartz andesites and dacites of magma mixing and mingling origin (no. 13 in Fig. 1), the Ilba Stone Rosette andesitic subaqueous extrusion, with radial polygonal columns (no. 2 in Fig. 1), the Piatra Roşie hyaloclastites (no. 16 in Fig. 1 and Fig. 3) and the Pintea Cave rootless sequence of explosive volcaniclastics.

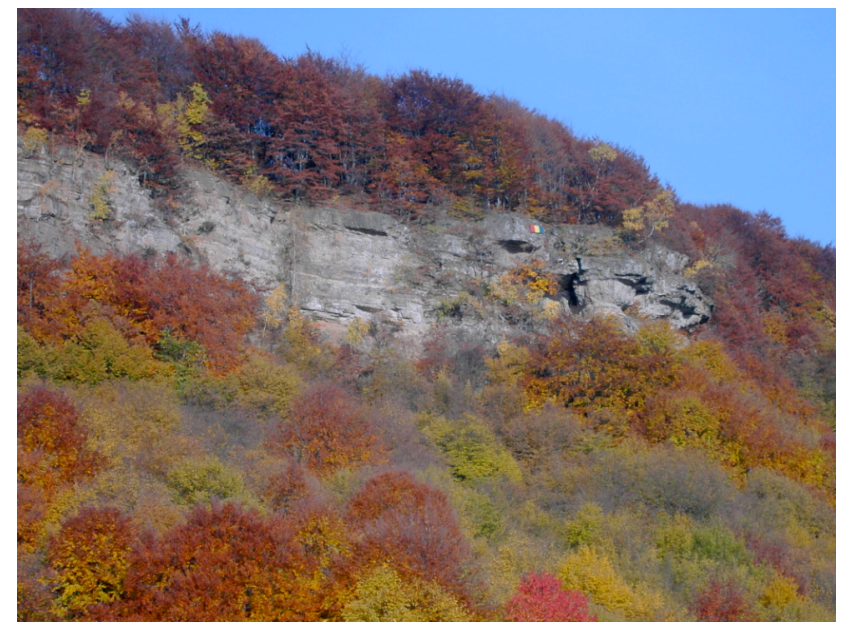

Fig. 3. The Piatra Rosie Hill, dacitic hyaloclastitic and reworked volcaniclastic deposits.

b. Mineral resources: the Mine Hill quarry (no. 9 in Fig. 1 and Fig. 4) - typical gold-base metal epithermal ore deposit (open pit), the Şuior quarry (no. 14 in Fig. 1) - the mined open pit of the Suior gold-rich mine and many outcrops, adits and shafts related to hydrothermal ore deposits (at Nistru, Băița, Săsar, Dealul Crucii, no. 4 in Fig. 1 and Fig. 5; Cavnic, etc.). It is worth to mention also some old or recent quarries with andesitic, dacitic or intrusive rock types used as building stones.

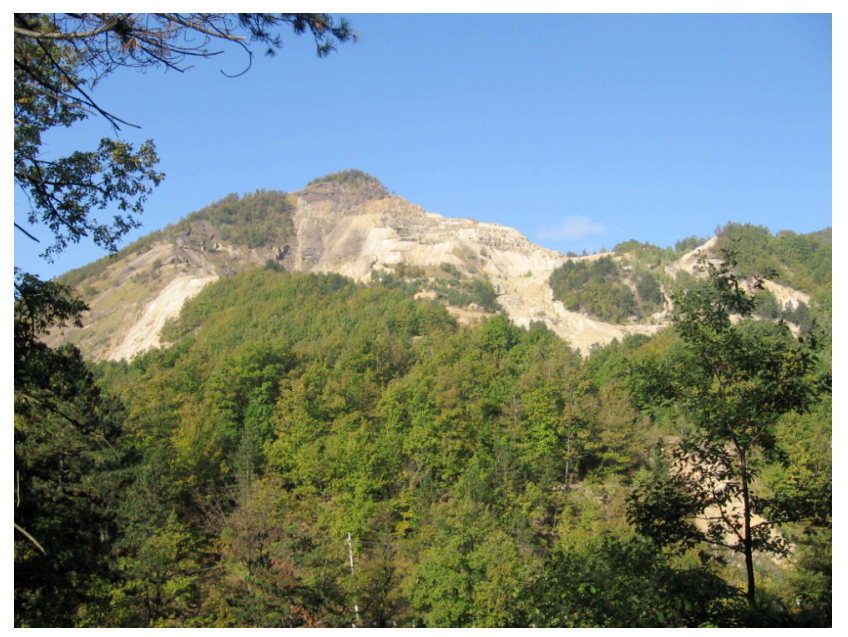

Fig. 4. The Mine Hill open pit of the Baia Sprie mine (base metal and gold ore deposit). 


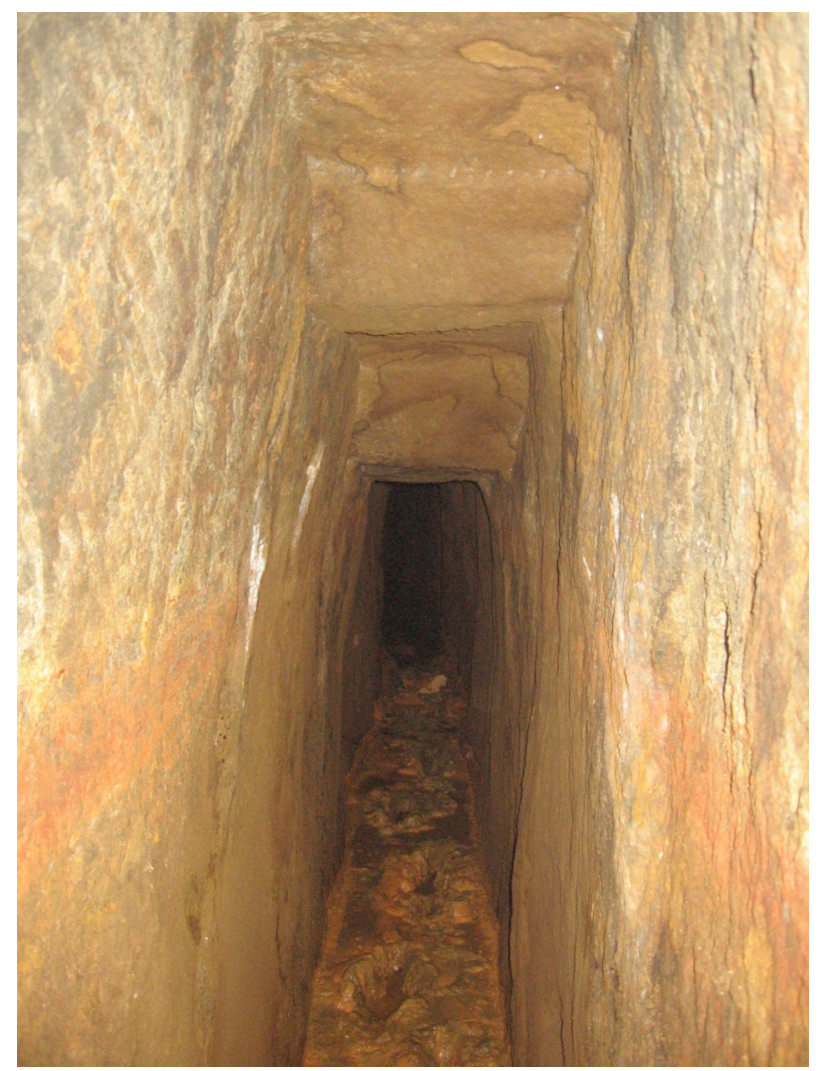

Fig. 5. The Dealul Crucii mine: Middle Age adit (handmade adit).

c. Minerals and fossils. Besides the Chiuzbaia fossiliferous reserve (unique in Europe; no. 8 in Fig. 1), other fossiliferous sites (flora and fauna) must be protected, as well as some minerals-hosting geosites (e.g., the big orthoclase crystals from the Laleaua Albă dacites; no. 13 in Fig. 1).

d. Landforms/landscapes. The conservation of the landforms and landscapes is another necessity. Some of the most significant landforms and landscapes- related sites could be the forthcoming natural, statutory-protected areas.

\section{Education}

The Baia Mare region as a potential Geopark could be an important research area attracting both Earth scientists and students and researchers in biology and environmental protection. The North University of Baia Mare will be involved in the future research developed in some specialized departments of the Faculty of Mineral Resources and Environment.

In accordance with the UNESCO guidelines, the Baia Mare Geopark could represent an opportunity for education in Geosciences appealing students, scholars and the public, attracting them with field trips, organized at different educational levels and on different geoscientific topics. A field trip along the southern part of the Gutâi Mts. shows aspects of the regional geology and mining and can be promoted for the students in Geology, Mining Engineering and Environmental Engineering. It consists of outcrops showing the representative igneous rocks from the area, (e.g., the Badenian rhyolitic ignimbrites, the Sarmatian and Pannonian andesite lavas), the specific hydrothermal alterations (e.g. adularia-sericite type) and some mine sites such as the Baia Sprie and Suior open pits. Some other field trips can be focused on more specific topics such as the volcanic structures (e.g., the Mogoşa volcano, the Dăneşti and Piatra Roşie interconnected domes complex and the Gutin cumulodome). The public will be attracted by field trips combining geology and landscape with tourism and entertainment, adding the old wooden churches and gates from Maramures County to a route including spectacular geosites such as the Rooster's Ridge, the Piatra Roşie hill and Mogosa Peak, the last one being also a tourist resort. Brochures, maps, guidebooks could be achieved and provided, including significant geosites along with other sites of cultural or historical value.

Educational centers could be settled in the Geopark (e.g., Izvoare tourist resort) with activities and logistics designated for students and scholars from all around the country or from abroad. Different lectures will be scheduled for students, teaching about: the regional geology, the evolution of the volcanism and the coeval hydrothermal activity, the importance of the mining in the region, its effects and the proposed remedial activities. Scholars will be educated to discover and enjoy the environment, the rocks, minerals and fossils and to be aware of the necessity of protection.

The education can be also developed in the Mineralogy Museum and the Mining Museum section of the History and Archaeology Museum from Baia Mare city with organized lectures about the formation of outstanding "mine flowers" and the history of mining in the region, respectively. The two museums are going to play an important role in promoting the Geopark activities through leaflets and brochures addressed to the public.

\section{Economic sustainable development}

The UNESCO guidelines emphasize that the main strategic goals of a Geopark are related to the stimulation of the economic activity for the sustainable development of the local communities.

The geotourism can be developed (Fülöp and Kovacs, 2006), based on: the significant geosites, the mining/archaeological, ecological and cultural sites, the future Mining Museums Network of recently closed mines (e.g., Cavnic, Baia Sprie, Herja) and the mine-based tourist routes including the old mining works (e.g., Middle Age mining-related sites, Fig. 5) and the museums from Baia Mare city. In this respect, the geotourism opens good opportunities for increasing the income of the communities living in the countryside, developing the small local business by providing traditional food and accommodation, geoproducts related to minerals / gems, craft products and souvenirs to the tourists.

The regional, mostly ecological agricultural production will be stimulated and markets will be organized to sell the products.

New jobs connected to the Geopark management (e.g., rangers and guides) will be also beneficial for the local communities.

\section{CONCLUSIONS}

The UNESCO philosophy related to the "Geopark concept" is to promote a territorial policy for sustainable development related to the Earth's heritage. The application of this concept in Baia Mare region is supported by its unique geological heritage, the long history of mining and the high value of its cultural heritage (some UNESCO/World Heritage Patrimony cultural sites e.g., Studia UBB, Geologia, 2009, 54 (1), 27 - 32 
wooden churches). A Geopark in the area could represent a real social and economic alternative for the development of the local communities after the cease of the mining-based activity. The impressive natural heritage, as well as the hundreds of years of mining in Baia Mare region, offer one of the best opportunity in Romania for establishing a new "Geological and Mining Park".

\section{R E F E R E N C E S}

Bud, I., Duma, S., Iştvan, D., Jurje, M., Kacso, C., Pop, L. \& Pop, S. 2006, Study on the potential regarding the mining industrial heritage of Maramureş county and its opportunities to be valued for touristic purposes. Maramureş County Council Archive, Baia Mare, 158 p. (in Romanian).

Csontos, L., Nagymarosy, A. 1998, The Mid-Hungarian line: a zone of repetead tectonic inversions. Tectonophysics, 297: 51-71.

Fülöp, A. 2003, The beginning of the volcanism in Gutâi Mts. Paleovolcanological and paleosedimentological reconstructions. Ed. Dacia, 134 p. (in Romanian).
Fülöp, A., Kovacs, M. 2006, Geotourism in Gutâi Mountains, Eastern Carpathians. Environment \& Progress, 6: 187-192 (in Romanian).

Iştvan, D., Minghiraş, T. 2004, Middle Age gallery from Dealul Crucii. Pro Unione, VII (1-2): 127-129 (in Romanian).

Kovacs, M. 2001, Subduction - related magmatism and associated metallogeny in Baia Mare Region (Romania). Romanian Journal of Mineral Deposits, 79 (2): 3-9.

Kovacs, M., Fülöp, A. 2003, Neogene volcanism in Gutâi Mts. (Eastern Carpathians). A review. Studia Universitatis Babeş - Bolyai, Geologia, XLVIII (1): 316.

Kovacs, M., Fülöp, A. \& Pécskay, Z. 2006, Neogene calcalkaline magmatism in Oas-Gutai Mts., Eastern Carpathians, Romania. Time and space evolution. Proceedings of the XVIIIth Congress of the CarpathoBalkan Geological Association, Belgrade, p. 290-294. www.unesco.org/science/earth/doc/geopark/2008guidelines 